\title{
Importance of the fiddler crab Uca pugnax to salt marsh soil organic matter accumulation
}

\author{
Cassondra R. Thomas ${ }^{1, *}$, Linda K. Blum \\ Department of Environmental Sciences, University of Virginia, PO Box 400123, Charlottesville, Virginia 22904-4123, USA
}

${ }^{1}$ Present address: Cardno TBE, 2257 Vista Parkway, Suite 19, West Palm Beach, Florida 33411, USA

\begin{abstract}
The potential influence of fiddler crab burrow density on the processes controlling organic matter (OM) accumulation was examined in Virginia salt marshes. As burrows may affect important chemical and biological processes that influence belowground plant production and decomposition, experimental manipulations were designed to modify fiddler crab burrow density by either increasing them (artificially constructed holes) or decreasing them (exclosures) and comparing them to areas naturally with and without fiddler crab burrows. The only significant difference among treatments was associated with the presence of holes without regard for whether they were artificial or natural. Higher burrow density resulted in an increase in soil redox potential, which most likely caused higher decomposition, even though sulfate-reduction rates were not different among treatments. Belowground production decreased with increased burrow density resulting in less OM addition to the soil. Higher decomposition and lower belowground production resulted in a net loss of $3 \mathrm{~g}$ $\mathrm{C} \mathrm{m}^{-2} \mathrm{yr}^{-1}$ in marshes with higher burrow densities, while areas with few to no burrows accumulated up to $245 \mathrm{~g} \mathrm{C} \mathrm{m}^{-2} \mathrm{yr}^{-1}$, equaling a surface accretion rate of $4 \mathrm{~mm} \mathrm{yr}^{-1}$. Examination of 6 other salt marshes in the region revealed a negative correlation between fiddler crab density and soil OM content, lending strength to the argument that bioturbation is a potentially important explanatory factor of OM accumulation in salt marshes and may influence how sea level rise impacts coastal marshes.
\end{abstract}

KEY WORDS: Carbon sequestration · Decomposition $\cdot$ Plant production $\cdot$ Sea-level rise $\cdot$ Long-term ecological research $\cdot$ LTER

Resale or republication not permitted without written consent of the publisher

\section{INTRODUCTION}

As sea levels continue to rise, coastal areas are under increasing threat of submergence (CCSP 2009). However, salt marshes can keep pace with sea level rise through surface accretion. Surface accretion can occur in 2 ways, mineral input and organic matter (OM) accumulation, the dominant mechanism depending on the environmental setting and ecology of the area. In spite of the vital role that OM accumulation plays in some marshes, little is known about why some marshes accumulate OM and others do not. Thus, understanding the factors controlling salt marsh soil OM accumulation is critical to determine if marshes in environments with low mineral sediment input will keep pace with sea level rise.
The balance between OM addition and decomposition determines the rate of soil OM accumulation (Good et al. 1982, Blum 1993, Blum \& Christian 2004). Soil OM can be added when dissolved organic carbon is sorbed to clay particles, particulate OM is imported by tides, or through belowground plant production and leaf litter addition. In salt marsh soils, particularly in Spartina alterniflora-dominated areas where leaf litter is mostly removed from the marsh surface by tides (Chalmers et al. 1985, Morris \& Bowden 1986, Morris 1988, Dame 1989, Cifuentes 1991, Dame et al. 1991), belowground production is the largest source of OM addition to the soil.

A variety of interrelated environmental factors affect Spartina alterniflora belowground production, including salinity (Smart \& Barko 1978, Linthurst \& Seneca 
1981), redox conditions (Mendelssohn et al. 1981, Mendelssohn \& McKee 1988), pore water sulfide concentration (Morris 1980, Koch et al. 1990), and nutrient availability (Woodhouse et al. 1974, Valiela et al. 1976, Morris 1980, Darby \& Turner 2008). Low redox conditions stimulate root growth as a stress response to oxidize the rhizosphere, sulfide reduces the plant's ability to take up nitrogen leading to increased root production, and high nutrient availability shifts the plant biomass production from roots to aboveground.

Decomposition is affected by many of the same factors affecting belowground production, but it is the type and availability of terminal electron acceptors that stand out as the principal control of the rate of decomposition (Howarth \& Hobbie 1982, Kristensen 2000 and references therein, Kostka et al. 2002). Terminal electron acceptors, such as oxygen, yield significant energy when carbon is oxidized, while sulfate and methane yield less energy. Therefore, carbon is generally oxidized more quickly under more oxidizing conditions than under reduced conditions. The type and availability of terminal electron acceptor present during decomposition can therefore influence the rate of decay.

Fiddler crab activity impacts the factors that affect both belowground production and decomposition. The burrow holes created by fiddler crabs increase the water-marsh surface interface allowing for greater permeation of important terminal electron acceptors, greater tidal flushing of the soil which lowers salt and sulfide concentrations, and excavation of belowground OM (Montague 1982). All of the factors may affect the balance between belowground production and decomposition such that OM accumulation is reduced compared to areas without fiddler crab burrow holes.

The overarching goal of our work was to understand what combination of factors explained why soil OM accumulation rates differed among salt marshes (Blum \& Christian 2004). Within that context, the specific goal was to determine if soil OM content could be altered by modifying burrow density. We hypothesized that the presence of burrows would decrease Spartina alterniflora belowground production rates and increase decomposition rates, thereby reducing OM accumulation in salt marsh soils. Our work was conducted in 2 regions of a mainland salt marsh on the eastern shore of Virginia colonized by short-form $S$. alterniflora. These marshes were similar in age, at similar elevations above sea level, but had different fiddler crab (Uca pugnax) abundance and soil OM content. We also monitored 6 other mainland salt marshes with different fiddler crab population densities to assess burrow density effects on soil OM content at a larger scale.

\section{MATERIALS AND METHODS}

Site description. The study sites were located on the eastern shore of Virginia, USA, adjacent to the Atlantic Ocean and were part of the Virginia Coast Reserve Long-Term Ecological Research (VCR LTER) project. The VCR LTER is a complex of barrier islands, lagoon, interlagoon marshes, and mainland marshes (Fig. 1). Two experimental plots were located in Philips Creek marsh $\left(37^{\circ} 46^{\prime} 7^{\prime \prime} \mathrm{N}, 75^{\circ} 83^{\prime} 43^{\prime \prime} \mathrm{W}\right)$ and received similar inputs of nutrients from the nearby tidal creek and precipitation (Tirrell 1995, Aiosa 1996). The dominant vegetation at each plot was short-form Spartina alterniflora. They had similar flooding frequencies and depths (measured by recording water level at each site over several tidal cycles). During a 1 yr period between

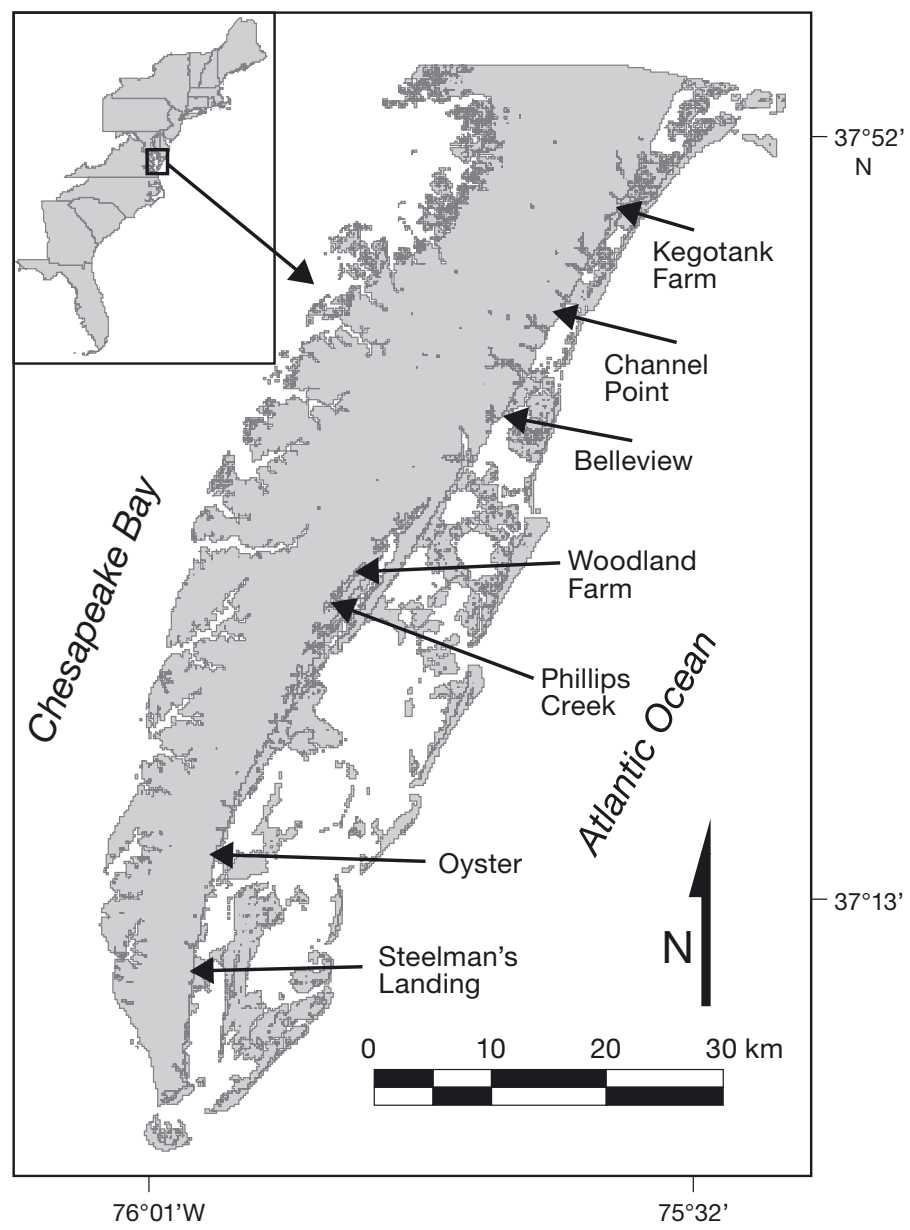

Fig. 1. Location of marshes used in this study. The 2 experimental sites are located along Phillips Creek $\left(37^{\circ} 46^{\prime} 7^{\prime \prime} \mathrm{N}\right.$, $75^{\circ} 83^{\prime} 43^{\prime \prime} \mathrm{W}$ ). The Upper Phillips Creek (UPC) and Lower Phillips Creek (LPC) sites are located within the same marsh and are approximately $500 \mathrm{~m}$ from one another. Six other marshes were sampled once during the study: Steelman's Landing, Oyster Harbor, Woodland Farm, Belleview Farm, Channel Point, and Kegotank Farm. These marshes are within $50 \mathrm{~km}$ to the north and south of Phillips Creek marsh 
September 2001 and August 2002 both plots flooded approximately 29 times to a maximum depth of $0.25 \mathrm{~m}$ (VCR LTER tide data). These 2 plots were studied because they differed in soil characteristics and burrow density.

The Lower Phillips Creek (LPC) plot soil was a sandy loam with $6 \%$ depth-averaged OM concentration $\left(0.039 \mathrm{~g} \mathrm{C} \mathrm{cm}^{-3}\right)$; roots penetrated approximately $20 \mathrm{~cm}$ deep, and the soil was similar in appearance from 0 to $25 \mathrm{~cm}$ depth. Aboveground $\left(440 \mathrm{~g} \mathrm{~m}^{-2}\right)$ and belowground biomass $\left(365 \mathrm{~g} \mathrm{~m}^{-2}\right)$ were relatively low with a root-to-shoot ratio of 0.83 , and burrow density was $32 \mathrm{~m}^{-2}$. The Upper Phillips Creek (UPC) plot soil was a sandy clay loam with $33 \%$ depth-averaged OM concentration $\left(0.074 \mathrm{~g} \mathrm{C} \mathrm{cm}^{-3}\right)$; the top $10 \mathrm{~cm}$ of soil was primarily organic; and below $10 \mathrm{~cm}$, the soil was primarily mineral with very little evidence of root penetration. Aboveground $\left(820 \mathrm{~g} \mathrm{~m}^{-2}\right)$ and belowground biomass $\left(902 \mathrm{~g} \mathrm{~m}^{-2}\right)$ were relatively high with a root-toshoot ratio of 1.17 , and a burrow density of $0 \mathrm{~m}^{-2}$.

Experimental design. Beginning in May 2001, 2 experimental manipulations were conducted for 18 mo. The manipulations consisted of either excluding fiddler crabs (and ultimately their burrows) at the LPC plot or adding artificial holes to simulate burrows at the UPC plot. Plots receiving no manipulations were also established at UPC and LPC. Therefore, there were 4 treatments: LPC No Holes (crab exclusion), LPC Holes (crabs naturally present), UPC No Holes (crabs naturally not present), and UPC Holes (artificial burrows added). Each treatment was replicated 3 times. The goal was to examine the effect of holes on OM accumulation.

At LPC, exclosures were constructed and fiddler crabs were removed. Existing burrow holes were destroyed by pushing excavated sediments into existing holes. The exclosures were $1.5 \mathrm{~m}^{2}$, while the experimental plots were $1 \mathrm{~m}^{2}$ to allow for sampling and plot maintenance within the exclosure with minimal disturbance to the plots. The exclosure frame was constructed of polyvinyl chloride (PVC) pipe with window screening attached on 4 sides. The screening was buried $15 \mathrm{~cm}$ into the soil to prevent fiddler crabs from burrowing under the exclosure, and aluminum flashing was attached to the rim of the exclosure to prevent fiddler crabs from crawling over the top. Exclosures were taller than the average high tide, reducing the likelihood of trapping animals at low tide. Empty capture jars (large Mason jars) were buried in the exclosures to aid in reducing the number of crabs in the plot (Nomann \& Pennings 1998). Crabs were removed from the exclosures weekly each summer and monthly during other seasons. At the beginning and end of the experiment, burrow density and diameter within all the plots at LPC were assessed to determine the success of the exclosure treatments.
Exclosure controls were also constructed at LPC to test the impact of their installation. Crabs were not removed and were able to move in and out of the exclosures through holes cut into the screening. Only platinum electrode potential (PtEP) and the number and size of crab burrows were measured in the exclosure control plots. No differences were found between the exclosure control plots and the unenclosed plots indicating that the differences between the exclosure treatment and the unexclosed treatment were not the result of the exclosures themselves.

At UPC, artificial burrow holes were created by excavating soil (20 $\mathrm{cm}$ deep, $2 \mathrm{~cm}$ diameter) with a soil auger. The material excavated from a plot was left on the soil surface. New holes were added monthly to compensate for holes filling in by collapse, sediment input, or root in-growth during the intervening period. Fiddler crabs usually plug their burrows at high tide and during night. No control for this type of activity was carried out. Approximately 50 holes per plot were maintained to replicate the burrow density assessed at LPC at the beginning of the experiment.

Extension to other marshes. Six other marshes, located within $50 \mathrm{~km}$ of Phillips Creek marsh, were examined to determine if the relationships between active fiddler crab populations and soil processes measured in the Phillips Creek marsh plots were similar (Fig. 1). The marshes represented the range of sediment and plant production characteristics typical of Virginia eastern shore mainland salt marshes (Ricker 1999). Triplicate plots were established in short-form Spartina alterniflora at similar elevations to those at Phillips Creek. Fiddler crabs inhabited 3 of the 6 marshes: Steelman's Landing, Bellevue, and Kegotank Farm.

Measurements. Pore water chemistry: To index terminal electron acceptor availability, PtEP was measured by coring the soil with a $60 \times 5.08 \mathrm{~cm}$ corer and inserting a platinum wire connected to a volt meter into small holes drilled every $1 \mathrm{~cm}$ in the side of the corer to a depth of $40 \mathrm{~cm}$. The holes were covered with self-sealing tape to prevent oxygen penetration. A saturated $\mathrm{KCl}$ silver-silver chloride reference electrode completed the circuit. Measurements were calibrated using ZoBell's solution (ZoBell 1946, Nordstrom 1977).

To measure dissolved ionic chemical species concentration, pore water was collected from 1, 5, 10, 15, 20 and $25 \mathrm{~cm}$ depths using an equilibrator sampler (Huang \& Morris 2003). Sterile glass $25 \mathrm{ml}$ vials filled with degassed deionized water were capped with $0.2 \mu \mathrm{m}$ Versapor ${ }^{\circledR}$ membrane filters and inserted into a PVC pipe sampler that had holes drilled in the side that corresponded to the above depths when the pipe was inserted flush with the marsh surface. The samplers were left in the marsh for at least $30 \mathrm{~d}$ to ensure complete equilibration (Bertolin et al. 1995). All sam- 
ples were appropriately fixed for the different analytes measured (ammonium, sulfate, and sulfide). Porewater sulfate concentrations were measured using an ion chromatograph, while ammonium and sulfide concentrations were measured colorimetrically (Cline 1969, Grasshoff et al. 1983, Otte \& Morris 1994).

Soil characteristics: To measure soil texture, $30 \mathrm{~cm}$ deep soil cores were taken, cut into $10 \mathrm{~cm}$ segments, and dried at $105^{\circ} \mathrm{C}$ to a constant mass. Each $10 \mathrm{~cm}$ segment was analyzed separately for texture using the method described by Liu \& Evett (1984). Briefly, this method uses a sodium hypochlorite solution to reduce OM interference during textural analysis, followed by dispersion of the mineral soil particles in a $40 \%$ sodium hexametaphosphate solution. The suspension was transferred to a hydrometer jar and density measurements were made with a calibrated hydrometer after $30 \mathrm{~s}$ and $2 \mathrm{~h}$. The percentage of sand, silt, and clay was determined using Stokes' Law (Liu \& Evett 1984).

To measure soil OM content, soil cores were collected monthly from each plot. Minimal compaction was ensured by having the soil levels within the corer no more than $0.1 \mathrm{~cm}$ different from those outside the corer. Burrows and created burrow holes were avoided during sampling. Subcores were taken at 2, 4, 6, 8, 10, 15,20 , and $25 \mathrm{~cm}$ depths. The subcores were dried at $105^{\circ} \mathrm{C}$ for 24 to $48 \mathrm{~h}$ to a constant mass. Percent OM was measured by loss-on-ignition at $450^{\circ} \mathrm{C}$ for approximately $4 \mathrm{~h}$. To calculate OM content, mass loss was normalized to the dried soil mass.

Aboveground plant characteristics: Aboveground biomass was collected in August 2001 and 2002 within a $0.0625 \mathrm{~m}^{2}$ quadrat. Live and dead leaves were separated. The length of live stems was measured, the number of stems was counted, and weight was measured after drying at $80^{\circ} \mathrm{C}$ to constant mass. The dried live stems from the 2002 biomass collections were ground with a Wiley mill to pass through a 40-mesh screen. Subsamples were sent to Actlabs (Tucson, Arizona) for stable sulfur isotope analysis. The remainder of the ground plant material was analyzed for carbon (C) and nitrogen $(\mathrm{N})$ with an EA 1108 CHNS-O Fisons elemental analyzer. A low $\delta^{34} \mathrm{~S}$ and a high $\mathrm{C}: \mathrm{N}$ ratio indicate high sulfide concentrations in the pore water (Bradley \& Morris 1990, Stribling et al. 1998)

Root growth: Root growth was measured using root growth litter bags (Blum 1993). These were constructed of $2 \mathrm{~mm}$ Nylon mesh, allowing roots and rhizomes to grow into them. The bags were approximately $2 \mathrm{~cm}$ wide, $0.5 \mathrm{~cm}$ thick, and $20 \mathrm{~cm}$ long and sewn at $10 \mathrm{~cm}$ intervals. Each section of the litter bag contained 1 to $2 \mathrm{~g}$ dried root material collected in January 2001 from UPC. Bags were buried to $20 \mathrm{~cm}$ depth with the top of the bag just below the marsh surface. Litter bags were collected approximately monthly from
July 2001 to September 2001 and March 2002 to November 2002. Live mass was separated from the original material. Most mass was roots but some rhizome mass was also included. The mass was dried at $80^{\circ} \mathrm{C}$ to a constant mass, and then ignited at $450^{\circ} \mathrm{C}$ for $4 \mathrm{~h}$ to obtain ash-free dry weight (AFDW).

Decomposition: Decomposition was evaluated in 2 ways: the stoichiometric relationship with C metabolism calculated based on sulfate-reduction rates (SRR) (Brock et al. 1994), and as mass loss from buried litter bags. To measure SRR, cores were collected and subcored with de-tipped $10 \mathrm{ml}$ syringes at $2,4,6,8,10,15,20$, and $25 \mathrm{~cm}$ depths. The subcores were immediately injected with $50 \mu \mathrm{H}_{2}{ }^{35} \mathrm{SO}_{4}$ (ca. $1 \mu \mathrm{Ci}$ ) and allowed to incubate in the dark at ambient temperature for 1 to $2 \mathrm{~h}$ depending on air temperature (Herlihy 1987 after Jørgensen 1978). Given the small quantity of $\mathrm{H}_{2}{ }^{35} \mathrm{SO}_{4}$ added to a $10 \mathrm{~cm}^{3}$ volume of soil (volumetric ratio of acid to soil was 1:1000) and the buffering capacity of sea water, it is unlikely that there was a significant change in $\mathrm{pH}$. The subcores were frozen in an ice and ethanol bath to halt the reaction and kept frozen until they were analyzed for radiolabeled sulfide production. Freezing of cores allowed for shortterm storage of samples (up to a few weeks) and safe handling under oxic conditions without significant loss of labeled sulfide (Jørgensen 1978). The total reduced inorganic sulfur (Fossing \& Jørgensen, 1989) method was employed to determine sulfide production. This single-step chromium-reduction method allowed measurement of all fractions of sulfide (free sulfide, $\mathrm{S}^{\circ}$, $\mathrm{FeS}$, and $\mathrm{FeS}_{2}$ ) in the subcores.

Root decomposition was measured in litter bags constructed of fine mesh fabric (bridal organdy) containing between 1 and $2 \mathrm{~g}$ of air-dried Spartina alterniflora root material collected in January 2001 from UPC. Litter bags were buried approximately $10 \mathrm{~cm}$ below the marsh surface. They were collected quarterly, gently washed, and examined for new root material growing into the bags. When found, the new roots were removed. The remaining litter was dried at $70^{\circ} \mathrm{C}$ to a constant mass, weighed then ignited at $450^{\circ} \mathrm{C}$ for $4 \mathrm{~h}$ to obtain AFDW. The AFDW was converted to $\mathrm{g} C$ by assuming AFDW was $40 \%$ C (Alexander 1977).

Statistical analysis. Data were log-transformed to fit the assumptions of normality. The experimental design did not include replicate treatments. Therefore, we conducted a 1-way analysis of variance (ANOVA) of the 4 treatments (crabs [LPC], crabs excluded [LPC], no crabs [UPC], artificial burrows [UPC]) to determine what differences existed. We did not detect statistically significant differences for any of the belowground variables measured between the crab exclusion and no crabs treatments, or between the crabs and artificial burrow treatments $(\mathrm{n}=3 ; \alpha$-level $=0.05)$. For all variables with the exception of aboveground plant biomass and density, 
the only significant difference among treatments was associated with the presence of holes without regard for whether the holes were artificial or crab-made (e.g. see ANOVA results for PtEP, Table 1). Consequently, for all the belowground variables measured, the crab burrow and artificial burrow treatments were combined into a single treatment type that is subsequently referred to as the 'Holes' treatment. The crab exclusion and no crab treatment were combined into 'No Holes' treatment. Lumping the treatments allowed the data to be reanalyzed by a 2-way ANOVA $(\mathrm{n}=3)$ with treatments of Holes or No Holes by site (UPC and LPC). Data are presented as Holes versus No Holes. When seasonal patterns were noticed, month was added to the model and analyzed as a 3-way ANOVA. A Pearson's pair-wise correlation was also performed. For all statistics, an $\alpha$-level of 0.05 was considered significant.

Principal components analysis (PCA) was done using variables measured at the 6 marshes. A PCA approach was used to explore which variables contributed most to differences among the regional marshes when all variables were considered together. Only those variables collected during a 1 wk period in August 2002 were used. The exceptions were root production and decomposition rates, which were measured between June 2001 and November 2002. A total of 22 different variables were included in the PCA.

To estimate the effective marsh surface area due to crab burrows, each burrow was assumed to be an open topped cylinder, $10 \mathrm{~cm}$ in height (Lim \& Diong 2003). The surface area of each burrow was calculated using the formula $a=2 \pi r^{2}+2 \pi r h$, where $r$ is the radius and $h$ is the height, and the total surface area of all burrows within $1 \mathrm{~m}^{2}$ was added to the surface area of the exclosure. Therefore, a burrow density of $32 \mathrm{~m}^{-2}$ with an average diameter of $1 \mathrm{~cm}$ increased the effective marsh surface area from $1 \mathrm{~m}^{2}$ to $1.11 \mathrm{~m}^{2}$, an $11 \%$ increase in surface area.

\section{RESULTS}

\section{Crab exclosure success}

At LPC, exclosures were installed to create the No Holes treatment. Crab burrow density before the exclosures were installed was $32 \mathrm{~m}^{-2}$ with diameters ranging from 1.0 to $3.5 \mathrm{~cm}$. Although fiddler crabs were regularly removed, burrow density increased to $37 \mathrm{~m}^{-2}$. However, the diameter of the burrows was reduced to $<1.0 \mathrm{~cm}$. The combined effect of smaller but more numerous burrows was a reduction in the effective marsh surface area. Inside the exclosures, the effective marsh surface area was $1.06 \mathrm{~m}^{2}$, compared to $1.13 \mathrm{~m}^{2}$ outside the exclosures. This reduction in surface area was sufficient to produce statistically significant differences in redox potential, root growth, and decomposition in litter bags (see below).
Table 1. (a) Platinum electrode potential (PtEP) as an indicator of redox potential (mV) for Upper Phillips Creek (UPC) and Lower Phillips Creek (LPC) marsh with holes created either by fiddler crabs (LPC Holes) or artificially (UPC Holes) and without holes, either naturally (UPC No Holes) or by crab exclusion (LPC No Holes). Data are depth averaged and presented as mean \pm 1 SE. (b) Two-way analysis of variance (ANOVA) testing for Site and Treatment difference, and 1-way ANOVA Within Treatment testing for site differences

\begin{tabular}{|c|c|c|c|c|}
\hline \multirow{2}{*}{ (a) Month } & \multicolumn{2}{|c|}{$\longrightarrow$ No Holes } & \multicolumn{2}{|c|}{ Holes } \\
\hline & UPC & LPC & UPC & LPC \\
\hline March & $-173.3 \pm 13.0$ & $-51.7 \pm 12.3$ & $-122.1 \pm 17.9$ & $45.9 \pm 17.4$ \\
\hline April & $43.5 \pm 15.9$ & $49.7 \pm 14.9$ & $-11.5 \pm 20.6$ & $145.5 \pm 19.4$ \\
\hline June & $-12.0 \pm 18.1$ & $109.4 \pm 16.8$ & $161.0 \pm 13.1$ & $65.4 \pm 12.1$ \\
\hline July & $44.8 \pm 25.5$ & $-20.7 \pm 24.4$ & $63.3 \pm 26.4$ & $32.2 \pm 26.1$ \\
\hline August & $-48.5 \pm 12.0$ & $67.7 \pm 11.0$ & $-3.7 \pm 15.5$ & $53.4 \pm 16.7$ \\
\hline September & $88.2 \pm 13.7$ & $-51.1 \pm 12.9$ & $91.3 \pm 15.4$ & $18.9 \pm 13.8$ \\
\hline November & $49.7 \pm 26.2$ & $-64.8 \pm 23.2$ & $17.1 \pm 15.1$ & $-9.8 \pm 18.6$ \\
\hline Average & $-0.6 \pm 9.0$ & $9.2 \pm 8.4$ & $29.0 \pm 8.9$ & $51.5 \pm 8.9$ \\
\hline \multicolumn{2}{|c|}{ (b) ANOVA results } & $\mathrm{p}$-values & & \\
\hline \multicolumn{2}{|c|}{ Site (UPC vs. LPC) } & 0.066 & & \\
\hline \multicolumn{2}{|c|}{ Treatment (Holes vs. No Holes) } & $<0.001$ & & \\
\hline \multicolumn{2}{|c|}{ Site $\times$ Treatment } & 0.472 & & \\
\hline \multicolumn{5}{|c|}{ Within Treatment } \\
\hline \multicolumn{2}{|c|}{ Holes (UPC vs. LPC) } & 0.079 & & \\
\hline \multicolumn{2}{|c|}{ No Holes (UPC vs. LPC) } & 0.417 & & \\
\hline
\end{tabular}

\section{Pore water chemistry}

No significant differences in PtEP were detected between burrows that had been constructed by crabs or artificially created (Holes) nor were differences detected between plots where crabs were experimentally excluded or did not occur naturally (No Holes) (Table 1). Holes significantly increased the PtEP of the soil $(\mathrm{p}<0.001)$ compared to plots without holes. Monthly averaged, depth-integrated PtEP in plots without holes was $2.7 \mathrm{mV}$, while it was $40.3 \mathrm{mV}$ in plots with holes. PtEP was significantly higher during the late spring and early summer, and lowest during the early spring and late fall ( $\mathrm{p}<$ 0.001). Although the soil texture was different at the 2 study sites (sandy loam and sandy clay loam, LPC and UPC respectively), PtEP was not significantly different between the sites (Table 1, Within Treatment ANOVA results). 
Pore water nutrients tended to not be affected by treatment (Fig. 2). Pore-water sulfate and sulfide concentrations were not affected by the presence of holes but were affected by month. Monthly averaged sulfate concentration tended to be higher in the spring and early summer than the late summer and fall, while sulfide was significantly higher in July and August compared to other months ( $p<0.001)$. Although ammonium was significantly higher in the No Holes plots than in the Holes plots $(\mathrm{p}<0.001)$, this was likely a result of high concentrations in the No Holes plots in April. The difference between the 2 treatments was

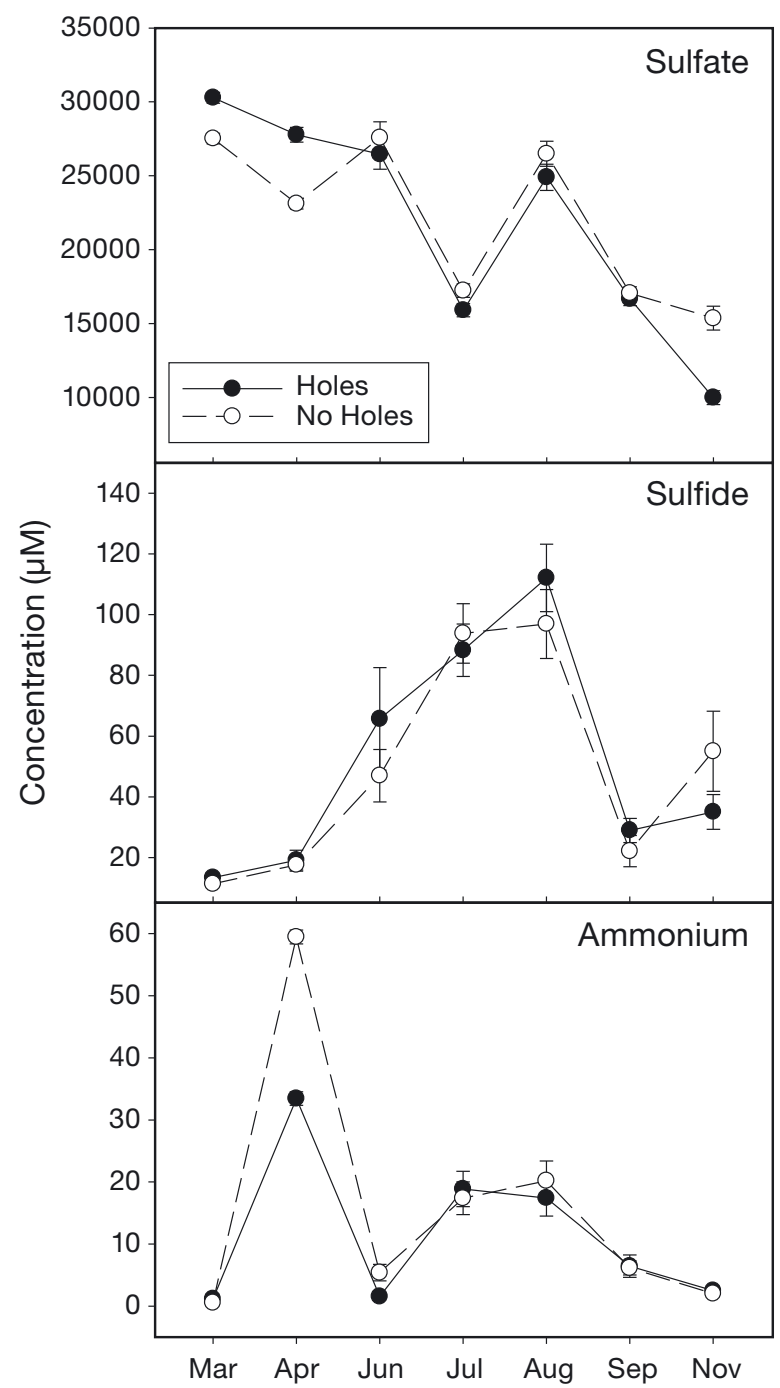

Fig. 2. Depth-average pore-water sulfate, sulfide, and ammonium concentrations at Upper Phillips Creek (UPC) and Lower Phillips Creek (LPC). The Holes treatment is the mean of plots with artificial holes at UPC and holes made by crabs at LPC, while the No Holes treatment is the mean of plots at UPC without a crab population and at LPC where crabs were excluded. Measurements were made at approximately monthly intervals from June 2002 to November 2002. Error bars represent $1 \mathrm{SE}$ of the mean, $\mathrm{n}=6$ most pronounced in April, disappearing over the summer. Concentrations were at their lowest levels in the fall $(\mathrm{p}<0.001)$.

\section{Plant dynamics}

Biomass and density were higher at UPC while there was no difference in stem height among the sites or the treatments (Table 2). Leaf chemistry, on the other hand, was significantly affected by treatment. The higher $\delta^{34} \mathrm{~S}$ ratio in the No Holes treatment indicated less sulfide stress. However, site was also a significant factor and there was a Site $\times$ Treatment interaction. The C:N ratio was not affected by Treatment but there was a Site $\times$ Treatment interaction, implying soil texture or factors related to fiddler crab activity other than those associated with burrows may also play a role in $\mathrm{N}$ uptake.

Belowground plant production was significantly higher in the No Holes plots than in the Holes plots ( $\mathrm{p}=$ 0.033) (Fig. 3). Root growth was at its lowest for both treatments in June, but at its highest in July in the No Holes treatments. Root growth was negatively correlated (-0.55) with PtEP ( $p=0.042)$, but no significant correlation was detected between root production and sulfide concentrations.

\section{Decomposition}

Decomposition estimated from SRR was not significantly different between the Holes and No Holes treatments (Fig. 4). The highest SRR were measured in March and were lowest in the late fall $(p=0.01)$. There was a weak, but significant, correlation between SRR and ammonium $(\mathrm{r}=0.222, \mathrm{p}<0.001)$ and between SRR and root growth $(r=0.10, p=0.045)$ for the Holes treatment. The correlations between SRR, pore water ammonium concentration, and root growth were not significant for the No Holes plots.

Decomposition measured as mass loss in litter bags was significantly higher in the plots with holes than in those without holes ( $p<0.001$ ) (Fig. 5). The gain in \% AFDW remaining observed in June 2002 was likely due to roots growing into the litter bags where they subsequently died before the litter bags were sampled; thus, rendering the new roots indistinguishable from the original material. This resulted in an underestimation of decomposition. Thus, the fact that a significant difference was observed between litter bag decomposition in the Holes and No Holes treatments suggests that the decay in the No Holes treatment, where root growth was greatest, may have been even greater than that which was measured. 
Table 2. Spartina alterniflora. (a) Leaf metrics and chemistry for plants grown in the presence of holes created by fiddler crabs (LPC) or artificially (UPC), or in the absence of holes due to either exclusion of crabs (LPC) or lack of a crab population (UPC) at Phillips Creek marsh sites. The carbon:nitrogen (C:N) molar ratio and sulfur (S) stable isotope ratio can be indicators of plant sulfide stress. Numbers are means $\pm 1 \mathrm{SE}$. (b) ANOVA results for 2-way AOVA testing for Site and Treatment effect

\begin{tabular}{|c|c|c|c|c|c|}
\hline (a) Treatment & Stem height $(\mathrm{cm})$ & Stem density (no. $\mathrm{m}^{-2}$ ) & Biomass $\left(\mathrm{g} \mathrm{m}^{-2}\right)$ & $\mathrm{C}: \mathrm{N}$ & $\delta^{34} \mathrm{~S}(\%)$ \\
\hline LPC No Holes & $26.4 \pm 5.4$ & $456 \pm 230.4$ & $394.1 \pm 172.5$ & $18.4 \pm 4.9$ & $3.8 \pm 2.8$ \\
\hline UPC No Holes & $24.4 \pm 2.5$ & $1525.3 \pm 467.6$ & $799.2 \pm 151.8$ & $27.8 \pm 2.4$ & $9.5 \pm 2.0$ \\
\hline LPC Holes & $24.7 \pm 2.8$ & $677.3 \pm 343.6$ & $432.5 \pm 112.6$ & $23.1 \pm 0.6$ & $-3.1 \pm 2.0$ \\
\hline UPC Holes & $21.1 \pm 5.9$ & $1688 \pm 567.9$ & $645.3 \pm 218.8$ & $24.9 \pm 4.6$ & $10.5 \pm 0.9$ \\
\hline (b) ANOVA & \multicolumn{5}{|c|}{$\mathrm{p}$-values } \\
\hline Site & 0.171 & $<0.001$ & $<0.001$ & 0.001 & $<0.001$ \\
\hline Treatment & 0.229 & 0.278 & 0.411 & 0.529 & 0.035 \\
\hline Site $\times$ Treatment & 0.691 & 0.867 & 0.177 & 0.017 & 0.010 \\
\hline
\end{tabular}

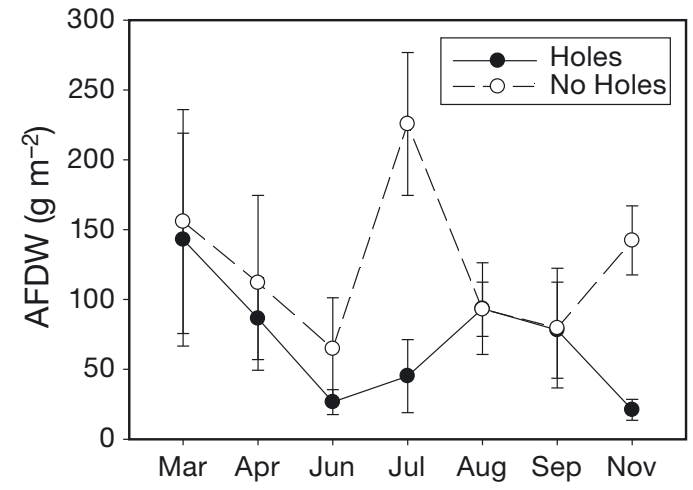

Fig. 3. Root production (Smalley 1958) expressed as ash-free dry weight (AFDW) for the 2002 growing season measured at Phillips Creek marsh from March 2002 to November 2002. The Holes treatment is the mean of plots with artificial holes at Upper Phillips Creek (UPC) and holes made by crabs at Lower Phillips Creek (LPC), while the No Holes treatment is the mean of plots at UPC without a crab population and at LPC where crabs were excluded. Error bars represent 1 SE of the mean, $\mathrm{n}=6$

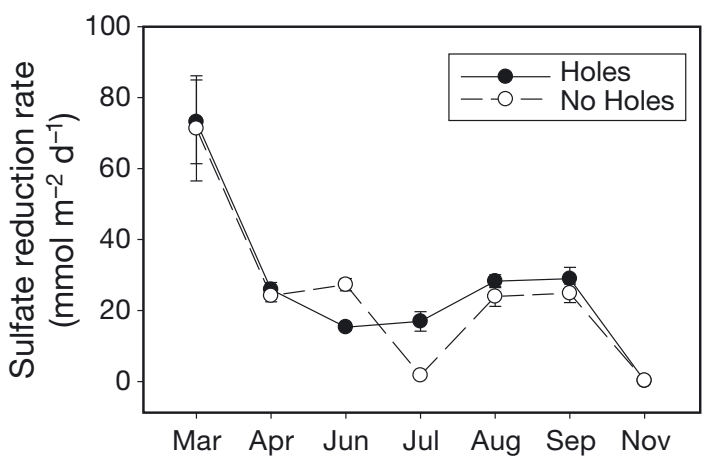

Fig. 4. Depth- and time-averaged sulfate-reduction rates in the top $20 \mathrm{~cm}$ of soil during the 2002 growing season (March 2002 to November 2002) measured at Upper Phillips Creek (UPC) and Lower Phillips Creek (LPC). The Holes treatment is the mean of plots with artificial holes at UPC and holes made by crabs at LPC, while the No Holes treatment is the mean of plots at UPC without a crab population and at LPC where crabs were excluded. Error bars represent 1 SE of the mean, $n=6$

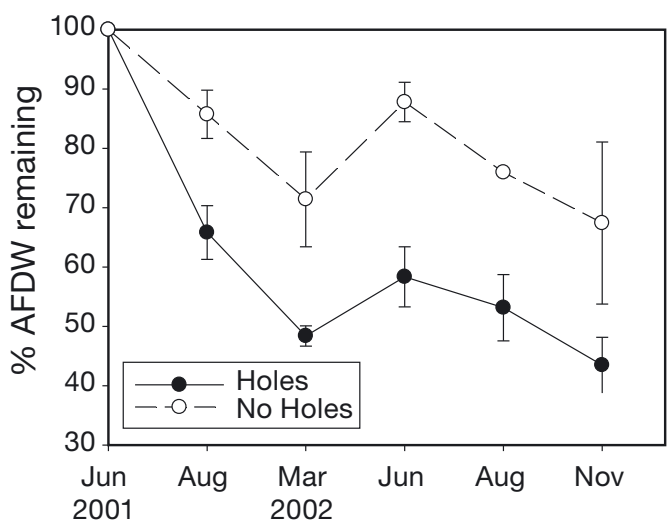

Fig. 5. Decomposition expressed as loss in organic matter (\% AFDW remaining) in buried litter bags incubated in Upper Phillips Creek (UPC) and Lower Phillips Creek (LPC) from June 2001 to November 2002. The Holes treatment is the mean of plots with artificial holes at UPC and holes made by crabs at LPC, while the No Holes treatment is the mean of plots at UPC without a crab population and at LPC where crabs were excluded. Error bars represent $1+\mathrm{SE}$ of the mean, $\mathrm{n}=6$, except

for the No Holes treatment in August 2002 where $n=3$

When $\mathrm{C}$ mineralization $\left(\mathrm{g} \mathrm{C} \mathrm{m}^{-2} \mathrm{yr}^{-1}\right)$ estimated from annual sulfate reduction was expressed as a percentage of litter bag decomposition, a greater proportion of the litter bag decay could be accounted for by sulfate reduction in the No Holes plots $(70 \%)$ than in the Holes plots $(56 \%)$. This result suggests that the higher PtEP found in the Holes plots altered decomposition to favor more energetically efficient processes, such as aerobic respiration or Fe(III) reduction.

\section{Organic matter accumulation}

Root production was higher than decomposition except in UPC Holes plots (Table 3). The UPC No Holes treatment showed the greatest difference between root growth and decomposition among all treatments, 
Table 3. Calculated organic matter (OM) accumulation in $\mathrm{g}$ carbon $(\mathrm{C}) \mathrm{m}^{-2} \mathrm{yr}^{-1}$ at Phillips Creek marsh in plots with holes made by crabs (LPC) or artificially (UPC), and without holes due to crab exclusion (LPC) or absent crab populations (UPC). Conversion from g dry weight to $\mathrm{g} \mathrm{C}$ was made assuming $40 \%$ of plant dry weight is C (Alexander 1977). Root production and decay are the mean \pm 1 standard deviation $(\mathrm{SD})$

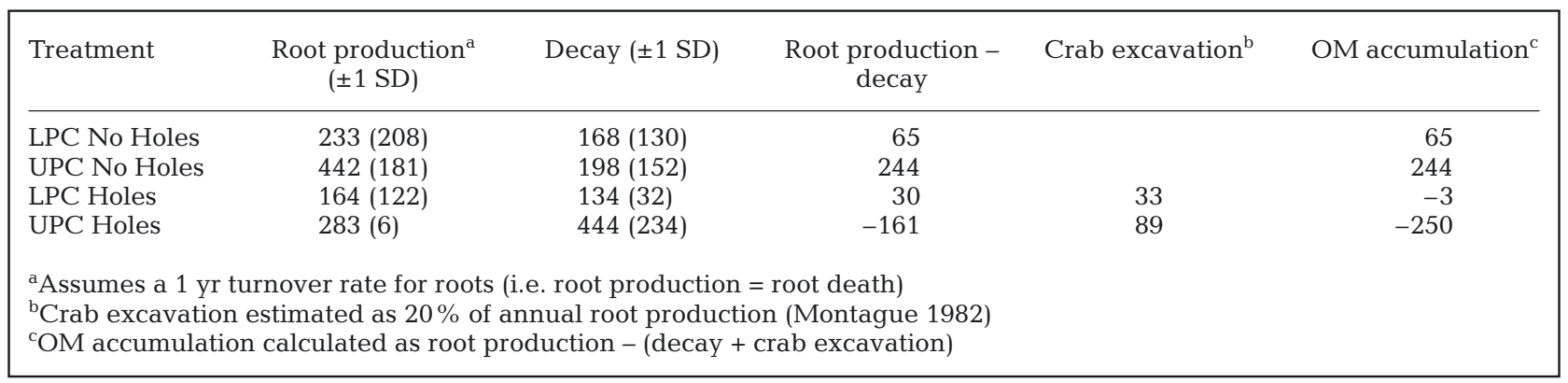

and therefore, the greatest potential for OM accumulation to occur, assuming root growth was equal to root death. All plots except UPC Holes accumulated OM. However, when crab burrowing activity was added to the carbon balance, OM accumulation in the Holes treatments became negative, indicating a loss of OM from the soil.

\section{Comparison to marshes within the region}

To provide a context for the experimental results from Phillips Creek marsh and determine if fiddler crab activity is an important variable to consider in salt marsh response to sea-level rise, soil properties, root production, and decomposition were measured in 6 other marshes. The first 3 principal components of a PCA analysis of 22 variables accounted for $47 \%$ of the

Table 4. Principle Components Analysis (PCA) of 19 variables in 6 representative mainland salt marshes of Virginia coastal lagoons. Numbers are mean (top number) and $1 \mathrm{SE}$ (bottom number) of the PC score for triplicate measures of each variable in each marsh $(22$ variables $\times 6$ marshes $\times 3$ replicate plots in each marsh). Below that is the contribution of highly contributing variables to the PC. The amount of variability explained by each PC is indicated in parentheses. PtEP: platinum electrode potential

\begin{tabular}{|lccc|}
\hline Marsh Type & PC1 $(23.2 \%)$ & PC2 $(12.8 \%)$ & PC3 $(10.9 \%)$ \\
\hline With crabs & -0.30683 & -0.15164 & 0.223056 \\
& $(0.11848)$ & $(0.070041)$ & $(0.103474)$ \\
Without crabs & 0.306827 & 0.151637 & -0.22306 \\
& $(0.106226)$ & $(0.149733)$ & $(0.125956)$ \\
OM content & 0.813 & 0.190 & 0.203 \\
Bulk density & -0.744 & -0.256 & 0.273 \\
Root growth & 0.525 & -0.017 & 0.115 \\
\% Sand & -0.367 & -0.689 & 0.066 \\
PtEP & -0.130 & 0.547 & -0.307 \\
Sulfide & -0.397 & 0.048 & 0.642 \\
\hline
\end{tabular}

variability (Table 4). For PC1, separation of sites was highly correlated with OM content (0.813), bulk density $(-0.744)$, and root production $(0.525)$. The mean OM content $( \pm 1 \mathrm{SE})$ of the marshes without fiddler crabs was $25.8 \pm 3.5 \%$, and for marshes with crabs was $12.8 \pm 1.4 \%$. For PC2, separation was correlated with $\%$ sand and redox. These results lend support to the findings at Phillips Creek.

\section{DISCUSSION}

The experimental design of this study posed challenging statistical analysis issues. The lack of true replication of experimental protocols between sites should have prevented a comparison of crab burrow treatments with sites as replicates. However, an assessment of the data using a 1-way ANOVA revealed that there was no difference between crab exclusions and no crab burrows (No Holes) or between natural crab burrows and artificial crab burrows (Holes) for belowground variables, which were the main variables driving the differences in OM accumulation. This lack of difference among sites by treatment provided support for assessing burrow effect as if true replication had been applied. This approach was further supported by the findings of the 6 regional marshes which exhibited similar patterns in OM accumulation between marshes where crab populations were naturally present or absent. Therefore, while we recognize the limitation of the experimental design, we believe our findings provide strong evidence that fiddler crab burrows reduce OM accumulation in marsh soils.

\section{Fiddler crab burrows and organic matter accumulation}

While fiddler crabs and their effects on different aspects of coastal wetland function have been well 
studied (Montague 1982, Bertness 1985, Nomann \& Pennings 1998, Botto \& Iribarne 2000, Kostka et al. 2002, Gribsholt et al. 2003, Kristensen \& Alongi 2006, Hyun et al. 2007), little was known about how burrows affect marsh function in the context of rising sea level and vertical accretion. Sea level rise along the Delmarva Peninsula is 2.75 to $3.5 \mathrm{~mm} \mathrm{yr}^{-1}$ (Davis 1987, Oertel et al. 1989), meaning that the Phillips Creek marsh must accrete $>3 \mathrm{~mm} \mathrm{yr}^{-1}$ in order to maintain its elevation relative to sea level. Mineral deposition is minimal in this marsh (Kastler \& Wiberg 1996); therefore, accretion depends on OM accumulation only.

Of the processes measured at Phillips Creek marsh with the potential to influence OM accumulation, belowground production was most affected by burrows. Burrows and artificial hole treatments experienced a 30 to $35 \%$ decrease in belowground production compared to plots without burrows or holes. Montague (1982) suggested that the relationship between crab activity and lower OM is a plant response to greater nutrient access, a conclusion based on the higher burrow-water ammonium concentrations compared with interstitial pore water. Valiela et al. (1976) and Darby \& Turner (2008) also found less roots with higher nutrient availability. Although we did not observe differences in pore water nutrients, or measure burrow-water nutrient concentrations, the higher decay rates observed in plots with holes suggested greater nutrient mineralization and availability to plants.

Alleviation of plant stress could also explain decreased belowground production in bioturbated soils. Spartina alterniflora increases root growth as a stress response (Valiela et al. 1976, Schubauer \& Hopkinson 1984). High pore water sulfide concentrations can stress plants resulting in decreased nitrogen uptake (Bradley \& Morris 1990). In the plots lacking holes, belowground production peaked in July and again in November, which corresponded to times of high pore water sulfide concentration. While the high $\delta^{34} \mathrm{~S}$ in leaf tissue from plots without holes seems contradictory to the hypothesis that these plants were stressed by sulfide, there may have been temporal variability in $\delta^{34} \mathrm{~S}$ values for $S$. alterniflora leaves due to variability in pore water sulfide (Stribling et al. 1998). However, the $\mathrm{C}: \mathrm{N}$ ratio for leaves in plots with no holes indicated that plants did not have decreased $\mathrm{N}$ uptake due to sulfide stress. Belowground production, however, was significantly greater when redox conditions were low, and redox was lower in plots without holes than in those with holes. Indeed, redox conditions may be the singular explanatory factor for belowground production differences.

Aboveground production was not considered to add significant OM to the soil as most standing dead plants are removed from the marsh with tidal activity
(Chalmers et al. 1985, Morris \& Bowden 1986, Morris 1988, Dame 1989, Cifuentes 1991, Dame et al. 1991). In addition, fiddler crab burrows were not found to affect aboveground vegetation. However, others have noted that altering fiddler crab burrow densities in the shortform Spartina alterniflora zone resulted in higher aboveground biomass when fiddler crabs were naturally present or artificial burrow holes were added (Bertness 1985). The differences in results may relate to other factors, such as latitude, crab burrow density, or geochemical factors, such as pore water chemistry. Crab burrow density in New England marshes was approximately 125 burrows per $\mathrm{m}^{2}$ (Bertness 1985), while Phillips Creek had a burrow density between 30 and 50 per $\mathrm{m}^{2}$, possibly explaining why no effect on aboveground vegetation was detected.

Decay in buried litter bags was affected by fiddler crab and artificial burrows: $74 \%$ more root material decomposed in plots with burrows than in those without. Yet, sulfate reduction rates were unaffected by holes, suggesting that holes enhance more energyefficient routes of decay, such as aerobic decomposition of Fe(III) reduction (Hyun et al. 2007). King (1988) noted a similar lack of association between sulfate reduction and bioturbation as evidenced by the lack of seasonality in the chromium-reducible sulfide pool, as would be expected with seasonal burrowing activity in marshes. Kostka et al. (2002) and Gribsholt et al. (2003) found that Fe(III) reduction could account for $100 \%$ of $\mathrm{C}$ mineralization in bioturbated sediments.

Measured root production and litter decomposition rates were used to calculate the OM accumulation potential (Table 3). Crab and artificial burrows shifted the balance between production and decay such that areas with no holes had greater OM accumulation potential than areas with holes. Montague (1982) reported that $20 \%$ of annual root production could be excavated by crab burrowing activity. When this loss was added to the OM accumulation calculation, the differences between sites were exacerbated (Table 3).

Using OM accumulation rates, bulk density, and \% soil OM, surface elevation changes were calculated (elevation change $=$ OM accumulation rate/bulk density $\times$ $\%$ soil OM) for each site. Lower Phillips Creek accretes $2 \mathrm{~mm} \mathrm{yr}^{-1}$, which is insufficient to maintain marsh area as sea level rises (Davis 1987, Oertel et al. 1989). Upper Phillips Creek was estimated to accrete $4 \mathrm{~mm} \mathrm{yr}^{-1}$ enabling it to keep pace with rising sea level. This estimate agrees closely with surface elevation changes attributed to root production (Blum \& Christian 2004) and sediment elevation table measurements of $4.3 \mathrm{~mm} \mathrm{yr}^{-1}$ (M. M. Brinson et al. unpubl.). These estimates were also supported by a Geographical Information Systems analysis comparing aerial photographs from 1938 and 1996 (Kastler \& Wiberg 1996). 


\section{Implications for marshes}

Determining what factors affected OM accumulation was critical for assessing potential marsh loss. Our work demonstrated that crab burrows and artificial holes shifted the balance between belowground production and decomposition towards reduced OM accumulation and potentially slower marsh surface accretion. Our conclusions are also supported by mesocosm experiments and modeling exercises carried out by Kristensen and colleagues in marine sediments (Kristensen 2000, Kristensen \& Holmer 2001) and mangroves (Kristensen \& Alongi 2006). Fiddler crab burrows may be an important predictor of salt marsh submergence as sea level rises.

Understanding the distribution of fiddler crabs and their impacts on marsh accretion provides needed insight into the interacting biological, chemical, and physical processes that determine salt marsh dynamics within the coastal landscape. Along the Delmarva Peninsula, marshes with fiddler crabs have lower soil OM content than those without. Their distribution is associated with sandier substrates compared to clay, while bulk density is not a factor (Thomas 2004). Bertness \& Miller (1984) found that New England fiddler crabs prefer intermediate substrate hardness for burrowing, with soft mud unable to support burrows and a thick root mat prohibitive to burrowing. Sandy substrates have intermediate hardness, while clay can be either too soft or too hard depending on soil moisture content. Sandy soils tend to be better drained than clay or peaty soils, increasing infiltration of terminal electron acceptors and altering the soil biogeochemistry in much the same way as burrows. Therefore, marsh geology may play as important a role in OM accumulation as fiddler crabs.

Acknowledgements. This research was funded in part by the National Science Foundation under Grants No. BSR-870233306, DEB-9211772, DEB-9411974 and DEB-0080381. We thank A. Mills and 2 anonymous reviewers for their helpful comments.

\section{LITERATURE CITED}

Aiosa JD (1996) Microbial metabolism of DOC. MS thesis, University of Virginia, Charlottesville, VA

Alexander M (1977) Introduction to soil microbiology, 2nd edn. John Wiley And Sons, New York, NY

Bertness MD (1985) Fiddler crab regulation of Spartina alterniflora production on a New England salt marsh. Ecology 66:1042-1055

Bertness MC, Miller T (1984) The distribution and dynamics of Uca pugnax (Smith) burrows in a New England salt marsh. J Exp Mar Biol Ecol 83:211-237

Bertolin A, Rudello D, Ugo P (1995) A new device for in-situ pore-water sampling. Mar Chem 49:233-239

Blum LK (1993) Spartina alterniflora root dynamics in a Vir- ginia marsh. Mar Ecol Prog Ser 102:169-178

Blum LK, Christian RR (2004) Belowground production and decomposition along a tidal gradient in a Virginia salt marsh. In: Fagherzzai S, Marani M, Blum LK (eds) Ecogeomorphology of tidal marshes. Coastal and estuarine studies 59. American Geophysical Union, Washington, DC, p 47-75

$>$ Botto F, Iribarne O (2000) Contrasting effects of two burrowing crabs (Chasmagnathus granulate and Uca uruguayensis) on sediment composition and transport in estuarine environments. Estuar Coast Shelf Sci 51:141-151

> Bradley PM, Morris JT (1990) Influence of oxygen and sulfide concentration on nitrogen uptake kinetics in Spartina alterniflora. Ecology 71:282-287

Brock TD, Madigan MT, Martinko JM, Parker J (1994) Biology of microorganisms. Prentice-Hall, Englewood Cliffs, NJ

CCSP (2009) Coastal sensitivity to sea-level rise: a focus on the mid-Atlantic region. A report by the US Climate Change Science Program and the Subcommittee on Global Change Research. Titus JG (coordinating lead author), Anderson KE, Cahoon DR, Gesch DB, Gill SK, Gutierrez BT, Thieler ER, Williams SJ (lead authors). US Environmental Protection Agency, Washington, DC

> Chalmers AG, Weigert R, Wolf P (1985) Carbon balance in a salt marsh: interactions of diffusive export, tidal deposition and rainfall-caused erosion. Estuar Coast Shelf Sci 21: $757-771$

- Cifuentes LA (1991) Spatial and temporal variation in terrestrially derived organic matter from sediments of the Delaware Estuary. Estuaries 14:414-429

Cline JD (1969) Spectrophotometric determination of hydrogen sulfide in natural waters. Limnol Oceanogr 14:454-458

Dame RF (1989) The influence of Spartina alterniflora on Atlantic Coast estuaries. Rev Aquat Sci 1:639-660

Dame RF, Spurrier JD, Williams TM, Kjerfve BJ and others (1991) Annual material processing by a salt marsh-estuarine basin in South Caroline, USA. Mar Ecol Prog Ser 72: 153-166

> Darby FA, Turner RE (2008) Below- and aboveground Spartina alterniflora production in a Louisiana salt marsh. Estuaries Coasts 31:223-231

> Davis GH (1987) Land subsidence and sea level rise on the Atlantic coastal plain of the United States. Environ Geol Water Sci 10:67-80

> Fossing H, Jørgensen BB (1989) Measurement of bacterial sulfate reduction in sediments: evaluation of a single-step chromium reduction method. Biogeochemistry 8:205-222

Good RE, Good NF, Frasco BR (1982) A review of primary production and decomposition dynamics of the belowground marsh component. In: Kennedy VS (ed) Estuarine comparisons. Academic Press, New York, NY, p 139-157

Grasshoff K, Ehrhardt M, Kremling K (1983) Methods of seawater analysis. Verlag Chemie, Weinheim

> Gribsholt B, Kostka JE, Kristensen E (2003) Impact of fiddler crabs and plant roots on sediment biogeochemistry in a Georgia saltmarsh. Mar Ecol Prog Ser 259:237-251

Herlihy AT (1987) Sulfur dynamics in an impoundment receiving acid mine drainage. $\mathrm{PhD}$ dissertation, University of Virginia, Charlottesville, VA

Howarth RW, Hobbie JE (1982) The regulation of decomposition and heterotrophic microbial activity in salt marsh soils: a review. In: Kennedy VS (ed) Estuarine comparisons. Academic Press, New York, NY, p 183-207

Huang X, Morris JT (2003) Trends in phosphatase activity along a successional gradient of tidal freshwater marshes on the Cooper River, South Carolina. Estuaries 26:1281-1290

> Hyun JH, Smith AC, Kostka JE (2007) Relative contributions of sulfate- and iron(III) reduction to organic matter miner- 
alization and process controls in contrasting habitats of the Georgia saltmarsh. Appl Geochem 22:2637-2651

Jørgensen BB (1978) A comparison of methods for the quantification of bacterial sulfate reduction in coastal marine sediments; measurements with radiotracer techniques. Geomicrobiol J 1:11-27

Kastler JA, Wiberg PL (1996) Sedimentation and boundary change in Virginia salt marshes. Estuar Coast Shelf Sci 42: $683-700$

King GM (1988) Patterns of sulfate reduction and the sulfur cycle in a South Carolina salt marsh. Limnol Oceanogr 33: 376-390

Koch MS, Mendelssohn IA, McKee KL (1990) Mechansim for the hydrogen sulfide-induced growth limitation in wetland macrophytes. Limnol Oceanogr 35:399-408

Kostka JE, Gribsholt B, Petrie E, Dalton D, Skelton H, Kristensen $E$ (2002) The rates and pathways of carbon oxidation in bioturbated saltmarsh sediments. Limnol Oceanogr 47:230-240

Kristensen E (2000) Organic matter diagenesis at the oxic/ anoxic interface in coastal marine sediments, with emphasis on the role of burrowing animals. Hydrobiologia 426:1-24

Kristensen E, Alongi DM (2006) Control by fiddler crabs (UCa vocans) and plant roots (Avicennia marina) on carbon, iron, and sulfur biogeochemistry in mangrove sediment. Limnol Oceanogr 51:1557-1571

Kristensen E, Holmer M (2001) Decomposition of plant materials in marine sediment exposed to different electron acceptors $\left(\mathrm{O}_{2}, \mathrm{NO}_{3}{ }^{-}\right.$, and $\left.\mathrm{SO}_{4}{ }^{2-}\right)$, with emphasis on substrate origin, degradation kinetics, and the role of bioturbation. Geochim Cosmochim Acta 65:419-433

Lim SSL, Diong CH (2003) Burrow-morphological characters of the fiddler crab, Uca annulipes (H. Milne Edwards, 1837) and ecological correlates in a lagoonal beach on Pulau Hantu, Singapore. Crustaceana 76:1055-1069

Linthurst RA, Seneca ED (1981) Aeration, nitrogen and salinity as determinants of Spartina alterniflora Loisel. growth response. Estuaries 4:53-63

Liu C, Evett JB (1984) Soil properties: testing, measurement, and evaluation. Prentice Hall, Englewood Cliffs, NJ

Mendelssohn IA, McKee KL (1988) Spartina alterniflora dieback in Louisiana: time-course investigation of soil waterlogging effects. J Ecol 76:509-521

Mendelssohn IA, McKee KL, Patrick WH Jr (1981) Oxygen deficiency in Spartina alterniflora roots: metabolic adaptation to anoxia. Science 214:439-441

Montague CL (1982) The influence of fiddler crab burrows and burrowing on metabolic processes in salt marsh sediments. In: Kennedy VS (ed) Estuarine comparisons. Academic Press, New York, NY, p 283-301

Morris JT (1980) The nitrogen uptake kinetics of Spartina alterniflora in culture. Ecology 61:1114-1121

Editorial responsibility: Steven Morgan,

Bodega Bay, California, USA
Morris JT (1988) Pathways and controls of the carbon cycle in salt marshes. In: Hook DD, Mckee WH, Smith HK, Gregory $\mathrm{J}$ and others (eds) The ecology and management of wetlands: ecology of wetlands, Vol 1. Croom Helm, Portland, OR, p 497-509

Morris JT, Bowden WB (1986) A mechanistic, numerical model of sedimentation, mineralization, and decomposition for marsh sediments. Soil Sci Soc Am J 50:96-105

Nomann BE, Pennings SC (1998) Fiddler crab-vegetation interactions in hypersaline habitats. J Exp Mar Biol Ecol 225:53-68

> Nordstrom DK (1977) Thermochemical redox equilibria of ZoBell's solution. Geochim Cosmochim Acta 41:1835-1841

> Oertel GF, Wong GTF, Conway JD (1989) Sediment accumulation at a fringe marsh during transgression, Oyster, Virginia. Estuaries 12:18-26

Otte ML, Morris JT (1994) Dimethylsulphoniopropionate (DMSP) in Spartina alterniflora Loisel. Aquat Bot 48: 239-259

Ricker LD (1999) Resistance to state change by coastal ecosystems under conditions of rising sea level. MS thesis, East Carolina University, Greenville, NC

Schubauer JP, Hopkinson CS (1984) Above- and belowground emergent macrophyte production and turnover in a coastal marsh ecosystem, Georgia. Limnol Oceanogr 29: 1052-1065

Smalley AE (1958) The role of two invertebrate populations, Littorina irrorate and Orchelimum fidicinium, in the energy flow of a salt marsh ecosystem. PhD dissertation, University of Georgia, Athens, GA

Smart RM, Barko JW (1978) Influence of sediment salinity and nutrients on the physiological ecology of selected salt marsh plants. Estuar Coast Mar Sci 7:487-495

Stribling JM, Cornwell JC, Currin C (1998) Variability of stable sulfur isotopic ratios in Spartina alterniflora. Mar Ecol Prog Ser 166:73-81

Thomas CR (2004) Salt marsh biogeochemistry and sediment organic matter accumulation. PhD dissertation, University of Virginia, Charlottesville, VA

Tirrell RL (1995) Response of sediment microbial community of Spartina alterniflora roots in a Virginia salt marsh. MS thesis, University of Virginia, Charlottesville, VA

> Valiela I, Teal JM, Persson NY (1976) Production and dynamics of experimentally enriched salt marsh vegetation: belowground biomass. Limnol Oceanogr 21:245-252

Woodhouse WW Jr, Seneca ED, Broome SW (1974) Propagation of Spartina alterniflora for substrate stabilization and salt marsh development. Technical Memorandum 46. Coastal Engineering Research Center, US Army Corps of Engineers, Fort Belvoir, VA

ZoBell CE (1946) Studies on redox potential of marine sediments. Bull Am Assoc Pet Geol 30:477-509

Submitted: November 12, 2009; Accepted: June 23, 2010

Proofs received from author(s): August 23, 2010 